\title{
Genetic divergence among common bean cultivars from precocious group
}

\section{Divergência genética entre cultivares de feijoeiro comum do grupo precoce}

\author{
Paulo Henrique Moron Pereira LEITE ${ }^{1}$; Marco Antonio Aparecido BARELLI ${ }^{2}$; Leonarda Grillo NEVES ${ }^{3}$; \\ Claudete Rosa da SILVA ${ }^{4}$; Taniele Carvalho de OLIVEIRA ${ }^{5}$ \\ 1 Aluno do Departamento Agronomia; Universidade do Estado de Mato Grosso - UNEMAT, Cáceres-MT; e-mail: \\ phmoron@gmail.com \\ ${ }^{2}$ Professor Dr. Adjunto, Departamento de Agronomia, Universidade do Estado de Mato Grosso - UNEMAT, Cáceres-MT; \\ e-mail: mbarelli@unemat.br \\ ${ }^{3}$ Professora Dra. Adjunta, Departamento de Agronomia, Universidade do Estado de Mato Grosso - UNEMAT, Cáceres- \\ MT; e-mail: leonardaneves@unemat.br \\ ${ }^{4}$ Professora Pós Doutora da Universidade Federal Rural da Amazônia-UFRA, Parauapebas-PA; e-mail: \\ clararizi@yahoo.com.br \\ 5 Autor para correspondência. Aluna do Programa de Pós-Graduação em Genética e Melhoramento de Plantas; \\ Laboratório de Recursos Genéticos \& Biotecnologia, Universidade do Estado de Mato Grosso - UNEMAT; Av.Santos \\ Dumont, s/n, Bairro Santos Dumont, Cidade Universitária - Bloco de Agronomia; Cáceres-MT, CEP: 78200-000; \\ e-mail: tani.ele@hotmail.com
}

Recebido em: 12-06-2014; Aceito em: 27-11-2014

\begin{abstract}
The objective of this work was to select parents to start a program of site breeding of common bean from the precocious group, by using morphological and agronomic traits under field conditions at EMPAER experimental unit located in Caceres County, Mato Grosso State, Brazil. Experimental design used was a randomized complete blocks, with three replications. The following characters were evaluated: number of days for flowering; plant cycle; medium plant height; medium height of first pod; medium of pod length; medium number of pods per plant; medium number of seeds per plant; medium number of seeds per pod; medium seeds weight and grain yield. Univariate variances analyses were used, Tukey test at $1 \%$ probability and besides cluster analysis based on Mahalanobis' generalized distance and UPGMA hierarchical method, through GENES software. Cultivars with the potential to be introduced into local improvement according to the analysis proceeded program are Iraí, Carioca, Carioca Pitoco, Bambuí and CNF 6911, due to their larger divergence and different agricultural potential for the characteristics that are important to the program as productivity and precocity.
\end{abstract}

Additional keywords: dissimilarity; genetic variability; multivariate analysis; Phaseolus vulgaris L.

\section{Resumo}

O trabalho teve por objetivo selecionar genitores para início de um programa de melhoramento local de feijoeiro comum, do grupo precoce, por meio de caracteres morfoagronômicos, em condições de campo, na unidade experimental da EMPAER, no município de Cáceres-MT. O delineamento experimental foi o de blocos ao acaso, com três repetições. Os caracteres avaliados foram: número de dias para florescimento, ciclo da planta, altura média da planta, altura média da inserção da primeira vagem, comprimento longitudinal médio das vagens, número médio de vagens por planta, número médio de sementes por planta, número médio de sementes por vagem, peso médio de sementes e produção de grãos. Foram empregados análise de variância univariada, teste de Tukey e análise de agrupamento com base na distância generalizada de Mahalanobis e o método Hierárquico UPGMA, empregando-se o recurso computacional GENES. As cultivares com potencial para serem introduzidas num programa de melhoramento local, em função das análises procedidas são Iraí, Carioca, Carioca Pitoco, Bambuí e CNF 6911, por apresentarem maior divergência e potencial agronômico diferenciado para as características que são importantes para o programa como produtividade e precocidade.

Palavras-chave adicionais: análise multivariada; dissimilaridade; Phaseolus vulgaris L.; variabilidade genética.

\section{Introduction}

The common bean (Phaseolus vulgaris L.) is a grain legume of great economic importance to Brazil. Considered one of the main foods of the Brazilian diet, it is the main source of protein in the diet, especially for the low-income population (Buratto et al., 2007).

The bean crop is among the cultivated species with shorter cycle, usually ranging from 85 to 90 days (Silva et al., 2007). Since the culture has short cycle, it is possible to be cultivated in three seasons during the year (Araújo \& Ferreira, 2006). 
The main characteristic to be used to evaluate the precocity of a culture is the time between the emergence until the appearance of the first flowers (Silva et al., 2007). The precocity enables rapid return on invested capital, greater flexibility in the management of production systems, escape from pests and diseases and from periods of water stress, in addition to water and energy savings in irrigated systems of the "Fall-Winter" crop (Souza et al., 2013).

Studies on genetic divergence provide parameters for the identification of genitors that, when crossed, enable greater heterotic effect, increasing the probability of obtaining superior genotypes in segregating generations (Lima et al., 2012). One way to estimate the genetic divergence is by multivariate analysis techniques, or associations among them. These alternatives are primarily intended to reduce the number of variables and hence simplify the obtaining of genetic distances. Their efficiency depends on the amount of variation that these new variables explain, regarding the existing variations in original characters (Correa \& Gonçalves, 2012).

The development of improved and uniform cultivars is a requirement of the market and should meet the current needs of increase in food production (Coelho et al., 2010). The choice of cultivars from precocious groups in common bean is of fundamental importance to reduce production costs, used in crop rotation and environmental stress escape, resulting in the success of the crop for the farmer. The aim of this work was to select genitors to start a program of local improvement of common bean from precocious group.

\section{Material and methods}

The experiment was conducted in 2005 in the experimental unit belonging to the Mato Grosso Company for Research and Extension (EMPAER) in the city of Cáceres-MT, located at latitude $16^{\circ} 43^{\prime} 42$ South and longitude $57^{\circ} 40$ ' 51 West with altitude of 118 meters, on BR 070, $12 \mathrm{~km}$ from Cáceres. 11 common bean cultivars from precocious group, coming from the National Center of Researches in Rice and Common Bean (CNPaf) (Table 1) were evaluated.

According to the Köppen's classification, the region has hot and humid tropical weather, with dry winter (Awa). The highest average temperatures occur in the wet season and the lowest in the dry season, configuring the local climate into two distinct seasons, with rainfall period ranging from October to March, and dry period from April to September (Neves et al., 2011). The soil of the region was classified as Eutrophic Red Yellow Podzol.

Table 1 - Characteristics of cultivars from precocious group. Cáceres-MT, 2005.

\begin{tabular}{|c|c|c|c|c|}
\hline No. & Cultivars & Color of the Flower & Color of the Seed & Color of the Halo \\
\hline 1 & Novo Jalo & $\begin{array}{l}\text { Rosy wings and light violet } \\
\text { standard }\end{array}$ & Yellow & Orange + purple \\
\hline 2 & Carioca similar & White & $\begin{array}{l}\text { Light beige with brown streaks } \\
\text { and punctuations }\end{array}$ & Beige \\
\hline 3 & Carioca Pitoco & White & $\begin{array}{l}\text { Light beige with brown streaks } \\
\text { and punctuations }\end{array}$ & Beige \\
\hline 4 & Jalo Precoce & Rosy & Yellow & Orange \\
\hline 5 & Goiano Precoce & White & $\begin{array}{l}\text { Light beige with brown streaks } \\
\text { and punctuations }\end{array}$ & Beige \\
\hline 6 & Irai & $\begin{array}{l}\text { Uneven, rosy wings and pur- } \\
\text { ple standard }\end{array}$ & $\begin{array}{l}\text { Beige with purple (wine- } \\
\text { colored) strias/punctuations }\end{array}$ & Yellow \\
\hline 7 & BRS Radiante & $\begin{array}{l}\text { Uneven, rosy wings and pur- } \\
\text { ple standard }\end{array}$ & $\begin{array}{l}\text { Beige with purple (wine-col- } \\
\text { ored) strias/punctuations }\end{array}$ & Yellow \\
\hline 8 & Carioca & White & Beige with brown stria & Beige \\
\hline 9 & Bambuí & Violet & Beige & Beige \\
\hline 10 & CNF 6911 & White & $\begin{array}{l}\text { Light beige with brown streaks } \\
\text { and punctuations }\end{array}$ & Beige \\
\hline 11 & CNFM 7119 & White & $\begin{array}{l}\text { Light beige with brown streaks } \\
\text { and punctuations }\end{array}$ & Beige \\
\hline
\end{tabular}

In fertilization, it was used $21 \mathrm{~kg}$ of a mixture consisting of NPK fertilizer formulated 4-30-10 with the supplements: Potassium Chloride; Zinc Sulfate and Boron. The cultivation was performed according to the needs of the culture. Spray irrigation was used to maintain the ideal humidity conditions for development of the crop, and the harvest was processed when $90 \%$ of the pods were dry.

The experimental design was in randomized blocks with three repetitions and the experimental unit 
consisted of four rows of four meters in length, spaced at $0.50 \mathrm{~m}$ and with an useful area of two central lines, ignoring $0.50 \mathrm{~m}$ at both ends of each line. Seeds were sown with density of eight seeds per linear meter.

The following characters were evaluated: number of days to flowering (FLOWER): number of days from seeding to the full opening of the first flower, in $50 \%$ of the plants in each plot; cycle of the plant (CYCLE): ratio between the number of days from emergence to harvest season, of the plants in each treatment; average plant height (HGHTP): expressed in $\mathrm{cm}$, obtained by measuring from the ground level to the tip of the plant, using a graduated measuring tape; average height of insertion of the first pod (HGHTINS): in cm, measured with a graduated scale, obtained by measuring from the soil base to the insertion of the first pod; average longitudinal length of the pods (ALLPd): in $\mathrm{cm}$, obtained by measuring with a ruler graduated from a longitudinal end to another end of the pod; average number of pods per plant (ANPP): obtained by averaging pods count per plant; average number of seeds per plant (ANSP): obtained by averaging the number of seeds produced per plant; average number of seeds per pod (ANSPd): obtained by averaging the number of seeds produced per plant; average seed weight (ASW): in grams (g), obtained by averaging the weighing of four samples of 100 seeds from each plot, with $12 \%$ moisture content; and grain production (GP): grain weight of useful plot processed in $\mathrm{kg} \mathrm{ha}^{-1}$.

Data were subjected to analysis of variance, the treatment means were compared by Tukey test at $1 \%$ probability. Genetic divergence was evaluated with use of the generalized Mahalanobis distance as dissimilarity measure, and for grouping of cultivars, the Unweighted Pair Group Method with Arithmetic Mean (UPGMA) was used in order to distinguish the most divergent materials, using the GENES computational resource (Cruz, 2013).

\section{Results and discussions}

Through the analysis of variance it is observed that there are significant probability differences $(p<0.01)$ using the $F$ test for the variables: FLOWER, CYCLE, HGHTP, ALLPd, ANSP, ANSPd and $A S W$, and significant at $(p<0.05)$ for the variables ANPP and GP, which shows genetic variability among cultivars. However the characteristic HGHTINS was not significant by Tukey test (Table 2).

Table 2 - Summary of analysis of variance combined for 11 common bean cultivars from the precocious group. Cáceres-MT, 2005.

\begin{tabular}{|c|c|c|c|c|c|c|c|c|c|c|c|}
\hline \multirow{2}{*}{ V } & \multirow{2}{*}{$\mathrm{GL}$} & \multicolumn{10}{|c|}{ Mean Squares ${ }^{1 /}$} \\
\hline & & FLOWER & R CYCLE & HGHTP & HGHTINS & ALLPd & ANPP & ANSP & ANSPd & ASW & GP \\
\hline Blocks & 2 & 4.93 & 1.48 & 34.23 & 5.39 & 1.58 & 1.37 & 242.56 & 0.85 & 18.87 & 1123.93 \\
\hline Cultivars & 10 & $16.45^{\star \star}$ & $12.95^{\star \star}$ & $102.92^{* *}$ & $14.76^{\mathrm{ns}}$ & $5.93^{* *}$ & $46.20^{*}$ & $2514.46^{\star *}$ & $1.05^{\star \star}$ & $75.75^{\star *}$ & $2719.42^{*}$ \\
\hline Residue & 20 & 0.27 & 0.58 & 13.91 & 6.98 & 0.18 & 14.87 & 710.35 & 0.31 & 4.63 & 1035.38 \\
\hline Total & 32 & - & - & - & - & - & - & - & - & - & - \\
\hline Mean & - & 41.60 & 73.48 & 47.47 & 15.80 & 11.27 & 23.29 & 126.55 & 5.38 & 27.95 & 124.98 \\
\hline CV (\%) & - & 1.25 & 1.04 & 7.85 & 16.71 & 3.83 & 16.55 & 21.05 & 10.47 & 7.70 & 25.74 \\
\hline
\end{tabular}

"FLOWER - number of days to flowering; CYCLE - number of days to harvest; HGHTP - average plant height; HGHTINS - average height of insertion of the first pod; ALLPd - average longitudinal length of the pods; ANPP - average number of pods per plant; ANSP - average number of seeds per plant; ANSPd - average number of seeds per pod; ASW - average weight of 100 seeds; GP - grain production. ${ }^{*}$, * significant at $1 \%$ and $5 \%$ probability level by the F test, respectively. ${ }^{N S}$ non significant, by the $F$ test.

Characteristics FLOWER, CYCLE, HGHTP, ALLPd and ASW showed low coefficients of variation, according to Pimentel-Gomes (2009). For the characteristics HGHTINS, ANPP and ANSPd medium values were shown, however, for the characteristics GP and ANSP the coefficient of variation was of high magnitude; however, this result can be explained because these characteristics are strongly influenced by the environment.

The means of 11 genotypes for the 10 evaluated characteristics are presented on Table 3 . The results showed significant differences for four evalu- ated characteristics, FLOWER, HGHTP, ANSP and ASW respectively, at $1 \%$ probability level. It is observed that for the characteristic FLOWER, the cultivars Carioca Pitoco and Carioca, whose flowering was reached to 44.33 days, differed significantly from the cultivars Goiano Precoce, Iraí and BRS Radiante, whose averages were 38.66 days. The cultivars Carioca Pitoco and Carioca differed statistically from the cultivar CNFM 7119. Ribeiro et al., (2004), evaluating the genetic variability for the duration of flowering subperiod in carioca bean genotypes, had a greater amplitude duration of the emergency- 
-flowering subperiod, oscillating from 29 to 45 days. MACHADO et al. (2008), evaluating the precocity in

precocious cowpea genotypes, obtained general average of the flowering character of 36.6 days.

Table 3 - Comparative analysis of the means of the 11 common bean cultivars, precocious group, compared to the ten evaluated characteristics. Cáceres-MT, 2005.

\begin{tabular}{|c|c|c|c|c|c|c|c|c|c|c|}
\hline \multirow{2}{*}{ Cultivars } & \multicolumn{10}{|c|}{ Means $^{1 /}$ of the evaluated ${ }^{2 /}$ characteristics } \\
\hline & $\overline{\text { FLOWER }}$ & CYCLE & HGHTP & HGHTINS & ALLPd & ANPP & ANSP & ANSPd & ASW & GP \\
\hline Novo Jalo & $41.33 a b c$ & $72.33 a$ & 43.26de & $11.96 a$ & $13.75 a$ & $21.13 a$ & $111.38 \mathrm{e}$ & $5.26 a$ & $32.75 a b$ & $123.80 a$ \\
\hline $\begin{array}{l}\text { Carioca } \\
\text { Similar }\end{array}$ & 42.33ab & $76.00 \mathrm{a}$ & $56.80 a$ & $14.86 a$ & $10.31 a$ & $24.73 a$ & $144.31 c$ & $5.83 a$ & $23.96 c$ & $134.75 a$ \\
\hline $\begin{array}{l}\text { Carioca } \\
\text { Pitoco }\end{array}$ & $44.33 a$ & $75.33 a$ & $53.06 \mathrm{~b}$ & $17.43 a$ & $10.45 a$ & $20.86 a$ & $129.60 d$ & $6.06 \mathrm{a}$ & $22.83 \mathrm{c}$ & $118.15 \mathrm{a}$ \\
\hline Jalo Precoce & $41.00 \mathrm{abc}$ & $6 a$ & $43.80 \mathrm{de}$ & $13.40 \mathrm{a}$ & $12.73 a$ & $15.40 \mathrm{a}$ & $70.75 \mathrm{~g}$ & $4.63 a$ & $32.45 a b$ & $84.50 \mathrm{a}$ \\
\hline $\begin{array}{l}\text { Goiano Pre- } \\
\text { coce }\end{array}$ & $38.66 c$ & 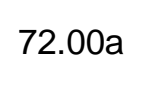 & 3 & a & $0 \mathrm{a}$ & $a$ & $8 f$ & 4 & $93 b$ & $92.56 a$ \\
\hline Iraí & $38.66 \mathrm{c}$ & $70.00 a$ & $46.40 \mathrm{cde}$ & $17.20 \mathrm{a}$ & $13.05 a$ & $28.26 a$ & $146.08 c$ & $5.16 a$ & $35.36 a$ & $200.08 a$ \\
\hline $\begin{array}{l}\text { BRS F } \\
\text { ante }\end{array}$ & $38.66 \mathrm{c}$ & $71.33 a$ & $52.36 \mathrm{~b}$ & $19.30 a$ & $12.46 a$ & $23.80 \mathrm{a}$ & $115.85 e$ & $4.86 a$ & $33.51 \mathrm{ab}$ & $138.53 a$ \\
\hline Carioca & $44.33 a$ & $76.00 \mathrm{a}$ & $52.13 b$ & $15.73 a$ & $10.43 a$ & $27.53 a$ & $170.46 a$ & $6.16 a$ & $22.81 \mathrm{c}$ & $126.66 a$ \\
\hline Bar & $44.00 \mathrm{a}$ & $6 a$ & $46.80 \mathrm{~cd}$ & $14.63 a$ & $10.41 a$ & $3 a$ & $159.54 b$ & $6.20 \mathrm{a}$ & $22.75 \mathrm{c}$ & $132.26 \mathrm{a}$ \\
\hline CNF 6911 & $44.00 \mathrm{a}$ & $74.33 a$ & $48.33 c$ & $16.06 a$ & $10.28 a$ & $27.26 a$ & $132.86 d$ & $4.93 a$ & $24.06 \mathrm{c}$ & $110.80 \mathrm{a}$ \\
\hline CNFM 7119 & $40.33 b c$ & $74.66 a$ & $43.00 \mathrm{e}$ & $18.66 a$ & $9.86 a$ & $21.53 a$ & $117.59 \mathrm{e}$ & $5.43 a$ & $26.00 c$ & $112.70 \mathrm{a}$ \\
\hline Mean & 41.6 & 73.48 & 47.47 & 15.8 & 11.27 & 23.29 & 126.55 & 5.38 & 27.95 & 124.98 \\
\hline
\end{tabular}

"Means followed by the same letter are not statistically different at $1 \%$ probability by the Tukey test. ${ }^{2}$ FLOWER - number of days to flowering; CYCLE - number of days to harvest; HGHTP - average plant height; HGHTINS - average height of insertion of the first pod; ALLPd - average longitudinal length of the pods; ANPP - average number of pods per plant; ANSP - average number of seeds per plant; ANSPd - average number of seeds per pod; ASW - average weight of 100 seeds; GP - grain production

The cultivar Carioca Similar, HGHTP of $56.80 \mathrm{~cm}$, differed significantly from the cultivars Carioca Pitoco, BRS Radiante and Carioca, whose height was less than $53.06 \mathrm{~cm}$, which did not differ from each other. The cultivars Novo Jalo, Jalo Precoce, Iraí, Bambuí, CNF 6911 and CNFM 7119 had an average plant height less than $48.33 \mathrm{~cm}$, and the cultivar that showed lower plant height was Goiano Precoce with $36.26 \mathrm{~cm}$ high. The mean for the characteristic HGHTP was $47.47 \mathrm{~cm}$, with amplitude of $20.54 \mathrm{~cm}$ in absolute values ranging from $56.80 \mathrm{~cm}$ for the cultivar Carioca Similar and $36.26 \mathrm{~cm}$ for the cultivar Goiano Precoce. According to Coelho \& Simões (2010), biometric variables used in the monitoring of plant growth, like plant height, are directly related to productivity.

For the characteristic ANSP, Carioca the cultivar was the one that showed the highest mean, showing an average of 170.46 seeds per plant. The cultivar that showed the lowest number of seeds per plant was Goiano Precoce, averaging 93.68 seeds per plant. The average number of seeds per plant was 126.55 seeds, with amplitude of 76.78 seeds in absolute values.

The cultivar Iraí showed higher ASW with $35.36 \mathrm{~g}$, differing significantly from the cultivars
Carioca Similar, Carioca Pitoco, Goiano Precoce, Carioca, Bambuí, CNF 6911 and CNFM 7119, which showed means lower than $26.0 \mathrm{~g}$, not differing from the other cultivars. ASW mean was $27.95 \mathrm{~g}$, with an amplitude of $12.61 \mathrm{~g}$ in absolute values.

The amplitude of dissimilarity values (13.674 to 1455.432) is indicative of the presence of genetic variability among cultivars. The pairs from the nearest cultivars, determined by the Generalized Mahalanobis Distance $\left(D^{2}{ }_{i i}\right)$, (Table 4) were between Carioca Pitoco and Carioca $\left(D_{i i^{\prime}}^{2}=13.674\right)$, followed by the combination Bambuí and CNF $6911\left(D^{2} i^{\prime}=17,000\right)$ and Carioca Pitoco and Bambuí $\left(D_{i i^{\prime}}^{2}=17.747\right)$, showing smaller dissimilarity among the other analyzed cultivars. These combinations have the same pattern of similarity, not recommended in programs of genetic improvement for hybridization resulting from the crossing between them, because the genetic variability among genotypes is essential in any improvement program, and cannot be restricted in such a way to make impractical the gains to be obtained by selection.

In turn, the largest dissimilarity was observed between pairs Carioca Pitoco and Iraí $\left(D_{i i^{\prime}}^{2}=1333.951\right)$ and between Iraí and Carioca $\left(D^{2} i^{\prime \prime}=1455.432\right)$. These pairs of cultivars showed 
high genetic divergence between them, being recommended in possible crosses, aiming to maximize heterosis in the progenies and to increase the possibility of existence of segregating in the advanced generations (Cruz et al., 2004).

Table 4 - Measures of genetic dissimilarity among 11 common bean cultivars, compared to the 10 evaluated characteristics, based on the Generalized Mahalanobis Distance $\left(D^{2}{ }_{i i}\right)$. Cáceres-MT, 2005.

\begin{tabular}{|c|c|c|c|c|c|c|c|c|c|c|c|}
\hline$\overline{\text { Cultivar }^{1}}$ & $1 / \quad 1$ & 2 & 3 & 4 & 5 & 6 & 7 & 8 & 9 & 10 & 11 \\
\hline 1 & 0.000 & 457.208 & 574.740 & 36.933 & 437.941 & 377.134 & 220.234 & 629.286 & 546.857 & 494.977 & 442.575 \\
\hline 2 & & 0.000 & 46.170 & 512.201 & 564.749 & 1017.363 & 701.919 & 69.072 & 38.758 & 61.424 & 151.497 \\
\hline 3 & & & 0.000 & 680.681 & 843.330 & 1333.951 & 975.577 & 13.674 & 17.747 & 21.691 & 303.246 \\
\hline 4 & & & & 0.000 & 291.754 & 223.410 & 95.999 & 753.921 & 639.687 & 612.191 & 392.428 \\
\hline 5 & & & & & 0.000 & 182.762 & 133.439 & 929.754 & 704.807 & 771.860 & 167.562 \\
\hline 6 & & & & & & 0.000 & 46.801 & 1455.432 & 1203.067 & 1220.195 & 571.641 \\
\hline 7 & & & & & & & 0.000 & 1075.523 & 886.614 & 897.324 & 386.329 \\
\hline 8 & & & & & & & & 0.000 & 27.726 & 30.889 & 357.122 \\
\hline 9 & & & & & & & & & 0.000 & 17.000 & 218.734 \\
\hline 10 & & & & & & & & & & 0.000 & 279.142 \\
\hline 11 & & & & & & & & & & & 0.000 \\
\hline
\end{tabular}

"11 - Novo Jalo; 2 - Carioca Similar; 3 - Carioca Pitoco; 4 - Jalo Precoce; 5 - Goiano Precoce; 6 - Iraí; 7 - BRS Radiante; 8 - Carioca; 9 - Bambuí; 10 - CNF 6911; 11 - CNFM 7119.

In turn, the largest dissimilarity was observed between pairs Carioca Pitoco and Iraí $\left(D_{i i i^{\prime}}^{2}=1333.951\right)$ and between Iraí and Carioca $\left(D_{i i^{\prime}}^{2}=1455.432\right)$. These pairs of cultivars showed high genetic divergence between them, being recommended in possible crosses, aiming to maximize heterosis in the progenies and to increase the possibility of existence of segregating in the advanced generations (Cruz et al., 2004).

It is recommended to avoid the choice for genitors based only on their differences, not taking into account their performance. The cross between divergent genitors that have superior performance regarding the main agronomic characteristics of the culture is recommended (Martins et al., 2002).

Through the Unweighted Pair Group Method with Arithmetic Mean UPGMA (Figure 1), subjected to the cut of $40 \%$ genetic distance and significant by the statistical program GENES, it was possible to form two distinct groups, being the Group I subdivided into two subgroups (Figure 1). The subgroup I.a is formed by the cultivars Carioca Pitoco, Carioca, Bambuí and CNF 6911, and has as main characteristics larger ANPP, ANSP and ANSPd. The subgroup I.b is formed by the cultivars Carioca similar and CNFM 7119, showing higher HGHTP and HGHTINS, and these two subgroups are formed by cultivars of Mesoamerican origin.

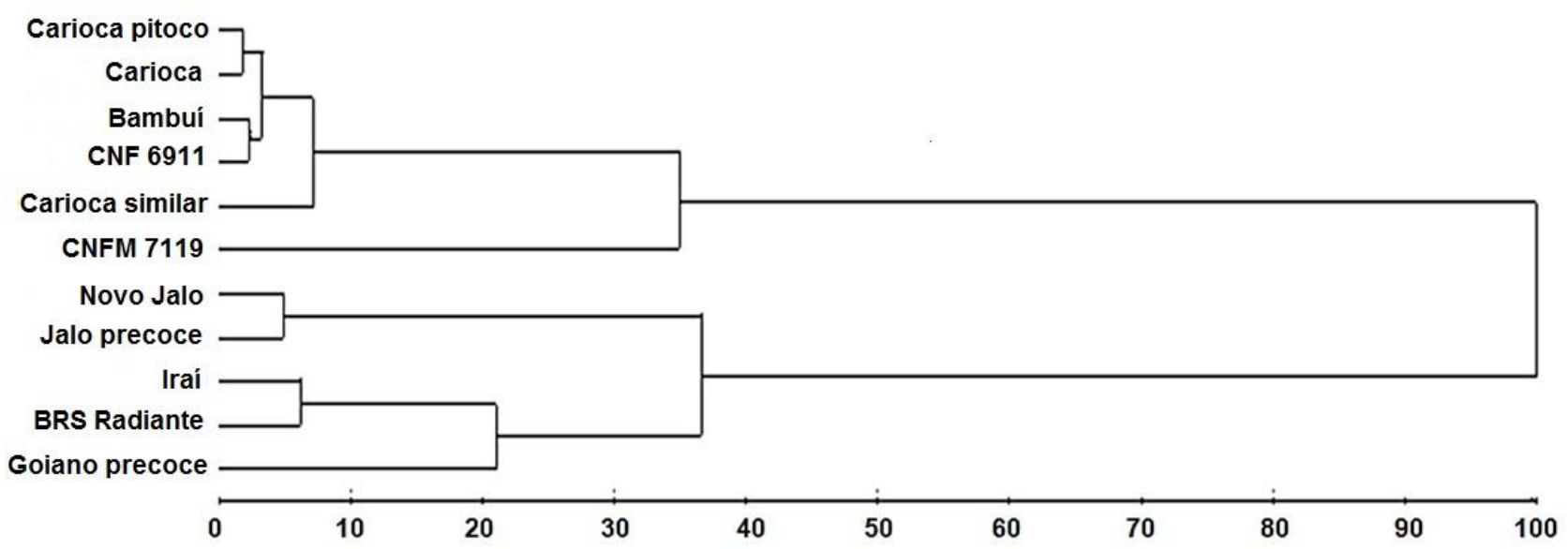

Figure 1 - Representative dendrogram of genetic dissimilarity among 11 common bean cultivars, obtained by Unweighted Pair Group Method with Arithmetic Mean (UPGMA), using the generalized Mahalanobis distance as dissimilarity measures. Cáceres-MT, 2005. 
Group II consists of 5 of the analyzed cultivars, was subdivided into two groups, allocating the cultivars Novo jalo and Jalo precoce in the subgroup II.a, whose main characteristic is the highest ALLPd. The cultivars Iraí, BRS Radiante and Goiano Precoce were allocated in the subgroup II.b, for presenting lower FLOWER and CYCLE and higher ASW and GP. Cultivars of group II belong to the Andean origin group.

Similar results were reported by Cabral et al. (2011), by estimating the genetic diversity through 57 common bean accessions by means of multivariate analyzes in the city of Muqui-ES and Kloster et al. (2011), by characterizing the genetic divergence of 22 common bean cultivars in Cáceres-MT.

The UPGMA dendrogram agrees with Mahalanobis, regarding the subgroup I.a, where the cultivars Carioca pitoco and Carioca; Bambuí and CNF 6911 are the most similar ones, and the most dissimilar cultivars are Iraí and Carioca, with the cultivar Carioca belonging to the subgroup I.a and the cultivar Iraí belonging to the subgroup II.b. In this group, there are cultivars from different origin groups, with a high value on genetic dissimilarity and very promising combinations. The cultivar Iraí has Andean origin and the cultivars Carioca, Carioca Pitoco, Bambuí and CNF6911 have Mesoamerican origin.

According to the agronomic performance and genetic diversity of analyzed cultivars, it is possible to indicate the following combinations for hybridization with the following materials: Iraí $x$ Carioca; Iraí x Bambuí; Iraí x CNF6911 and Carioca Pitoco x Iraí.

\section{Conclusions}

The cultivars with potential to be introduced at a local improvement program based on the proceeded analyzes are Iraí, Carioca, Carioca Pitoco, Bambuí and CNF 6911, due to their larger divergence and differentiated agronomic potential for the characteristics that are important to the program, like productivity and precocity.

\section{References}

Araújo GAA, Ferreira ACB (2006) Manejo do solo eplantio. In: Vieira C, Paula Júnior TJ, Borém A (Org) Feijão, 2rd edn, Viçosa. p.87-114

Buratto JS, Moda-Cirino V, Fonseca-Júnior NS, Prete CEC, Faria RT (2007) Adaptabilidade e estabilidade produtiva em genótipos precoces de feijão no Estado do Paraná. Semina 28(3):373-380.

Cabral PDS, Soares TCB, Lima ABP, Alves DS, Nunes JA (2011) Diversidade genética de acessos de feijão comum por caracteres agronômicos. Revista Ciência Agronômica 42(4):898-905.
Coelho CMM, Zilio M, Souza CA, Guidolin AF, Miquelluti DJ (2010) Características morfo-agronômicas de cultivares crioulas de feijão comum em dois anos de cultivo. Semina 31(1):1177-1186.

Coelho EF, Simões WL (2010) Produtividade do mamoeiro, cultivar Tainungn ${ }^{\circ} 1$, sob diferentes manejos de irrigação nos tabuleiros costeiros do nordeste. Magistra 22(1)35-40.

Correa AM, Gonçalves MC (2012) Divergência genética em genótipos de feijão comum cultivados em Mato Grosso do Sul. Revista Ceres 59(2):206-212.

Cruz CD (2013) GENES - a software package for analysis in experimental statistics and quantitative genetics. Acta Scientiarum 35(3):271-276.

Cruz CD, Regazzi AJ, Carneiro PCS (2004) Modelos Biométricos Aplicados ao Melhoramento Genético. 3rd edn. UFV. 480p.

Kloster GS, Barelli MAA, Silva CR, Neves LG, Paiva Sobrinho S, Luz PB (2011) Análise da divergência genética através decaracteres morfológicos em cultivares defeijoeiro. Revista Brasileira de Ciências Agrárias 6(3):452-459.

Lima DT, Santos CEM, Rocha MR, Rosado LDS, Alves FM (2012) Divergência genética entre genótipos de maracujazeiro azedo com base em vigor, incidência de doenças e características de frutos. Magistra 24(4):314-322.

Martins IS, Pires IE, Oliveira MC (2002) Divergência genética em progênies de uma população de Eucalyptus camaldulenses DEHNH. Floresta e Ambiente 9:81-89.

Machado CF, Teixeira NJP, Freire Filho FR, Rocha MM, Gomes RLF (2008) Identificação de genótipos de feijão-caupi quanto à precocidade, arquitetura da planta e produtividade de grãos. Revista Ciência Agronômica 39(1):114-123.

Pimentel-Gomes F (2009) Curso de estatística experimental.15rd edn. FEALQ. 451 p.

Ribeiro ND, Hoffmann Junior L, Possebon SB (2004) Variabilidade genética para ciclo em feijão dos grupos preto e carioca. Revista Brasileirade Agrociência 10(1):19-29.

Silva FB, Ramalho MAP, Abreu AFB (2007) Seleção recorrente fenotípica para florescimento precoce de feijoeiro 'Carioca'. Pesquisa Agropecuária Brasileira, 42(10):1437-1442.

Souza TLPO, Pereira HS, Faria LC, Wendland A, Costa JGC, Abreu AFB, Dias JLC, Magaldi MCS, Souza NP, Peloso MJD, Melo LC (2013) Cultivares de feijão comum da Embrapa e parceiros disponíveis para 2013. Embrapa. 6p. (Comunicado Técnico 211). 